The INL is a

U.S. Department of Energy

National Laboratory

operated by

Battelle Energy Alliance

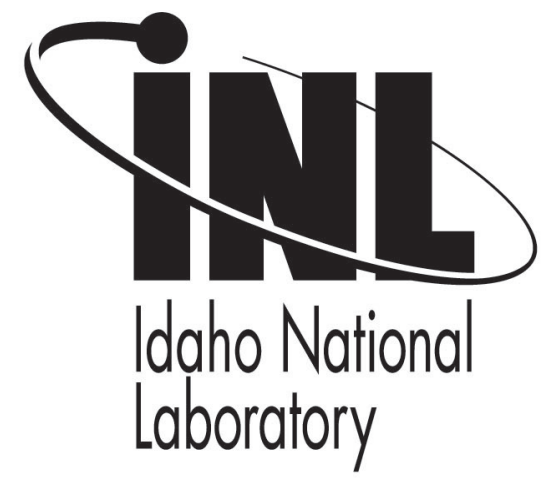

\title{
Integrated Operation of
}

the INL Hytest System and High-Temperature Steam Electrolysis for Synthetic Natural Gas Production

\section{Second International Meeting of the Safety and Technology of Nuclear Hydrogen Production, Control and Management}

Carl Stoots

Lee Shunn

James O'Brien

\section{June 2010}

This is a preprint of a paper intended for publication in a journal or proceedings. Since changes may be made before publication, this preprint should not be cited or reproduced without permission of the author. This document was prepared as an account of work sponsored by an agency of the United States Government. Neither the United States Government nor any agency thereof, or any of their employees, makes any warranty, expressed or implied, or assumes any legal liability or responsibility for any third party's use, or the results of such use, of any information, apparatus, product or process disclosed in this report, or represents that its use by such third party would not infringe privately owned rights. The views expressed in this paper are not necessarily those of the United States Government or the sponsoring agency. 


\title{
INTEGRATED OPERATION OF THE INL HYTEST SYSTEM AND HIGH-TEMPERATURE STEAM ELECTROLYSIS FOR SYNTHETIC NATURAL GAS PRODUCTION
}

\author{
Carl Stoots \\ Idaho National Laboratory, PO 1625, Idaho Falls, Idaho, 83415, carl.stoots@inl.gov \\ Lee Shunn \\ Idaho National Laboratory, PO 1625, Idaho Falls, Idaho,83415,lee.shunn@inl.gov \\ James O’Brien
}

Idaho National Laboratory, PO 1625, Idaho Falls, Idaho,83415,jzo@inl.gov

The primary feedstock for synthetic fuel production is syngas, a mixture of carbon monoxide and hydrogen. Current hydrogen production technologies rely upon fossil fuels and produce significant quantities of greenhouse gases as a byproduct. This is not a sustainable means of satisfying future hydrogen demands, given the current projections for conventional world oil production and future targets for carbon emissions. For the past six years, the Idaho National Laboratory has been investigating the use of high-temperature steam electrolysis (HTSE) to produce the hydrogen feedstock required for synthetic fuel production. High-temperature electrolysis water-splitting technology, combined with non-carbon-emitting energy sources, can provide a sustainable, environmentally-friendly means of largescale hydrogen production. Additionally, laboratory facilities are being developed at the INL for testing hybrid energy systems composed of several tightly-coupled chemical processes (HYTEST program). The first such test involved the coupling of HTSE, $\mathrm{CO}_{2}$ separation membrane, reverse shift reaction, and methanation reaction to demonstrate synthetic natural gas production from a feedstock of water and either $\mathrm{CO}$ or a simulated flue gas containing $\mathrm{CO}_{2}$. This paper will introduce the initial HTSE and HYTEST testing facilities, overall coupling of the technologies, testing results, and future plans.

\section{INTRODUCTION}

Although global oil demand decreased in 2008 and 2009, demand is expected to once again grow in 2010[1]. However, some researchers believe that world oil production capacity may have already peaked in early 2008 and is declining [2]. Also, the use of liquid hydrocarbon fuels results in significant greenhouse gas emissions and contributes to global warming. A hydrogen-based energy economy has been proposed, with goals of reduced oil consumption and reduced greenhouse gas emissions. However, the conversion process to a hydrogen-based energy economy will require decades due to the tremendous infrastructure already in place related to liquid hydrocarbons.

Synthetically-derived hydrocarbon fuels (synfuels) can represent an interim solution and a bridge to a future hydrogen economy. Synfuel production is a mature technology, and requires syngas - a mixture of hydrogen $\left(\mathrm{H}_{2}\right)$ and carbon monoxide $(\mathrm{CO})$ - as a feedstock. Traditionally, syngas and synfuel have been produced via coal gasification and partial oxidation of natural gas. Synfuel production from coal gasification follows the following simplified series of reactions $[3,4]$ :

$$
\begin{array}{ll}
\text { Gasification: } & 2 \mathrm{C}+1 / 2 \mathrm{O}_{2}+\mathrm{H}_{2} \mathrm{O} \rightarrow 2 \mathrm{CO}+\mathrm{H}_{2} \\
\text { Water gas shift } & \mathrm{CO}+\mathrm{H}_{2} \mathrm{O} \rightarrow \mathrm{H}_{2}+\mathrm{CO}_{2} \\
\text { F-T reaction } & \mathrm{CO}+2 \mathrm{H}_{2} \rightarrow \mathrm{CH}_{2}+\mathrm{H}_{2} \mathrm{O} \\
\text { Net reaction } & 2 \mathrm{C}+\mathrm{H}_{2} \mathrm{O}+1 / 2 \mathrm{O}_{2} \rightarrow \mathrm{CH}_{2}+\mathrm{CO}_{2} .
\end{array}
$$

As is noted in $[3,4]$, the actual series of reactions is much more complex. Similarly, synfuel production via partial oxidation (POX) of natural gas follows the following simplified path:

$$
\begin{array}{ll}
\mathrm{POX} & \mathrm{CH}_{4}+1 / 2 \mathrm{O}_{2} \rightarrow \mathrm{CO}+2 \mathrm{H}_{2} \\
\text { F-T reaction } & \mathrm{CO}+2 \mathrm{H}_{2} \rightarrow \mathrm{CH}_{2}+\mathrm{H}_{2} \mathrm{O} \\
\text { Net reaction } & 2 \mathrm{C}+\mathrm{H}_{2} \mathrm{O}+1 / 2 \mathrm{O}_{2} \rightarrow \mathrm{CH}_{2}+\mathrm{CO}_{2} .
\end{array}
$$

Steam methane reforming produces a syngas with a $\mathrm{H}_{2} /$ $\mathrm{CO}$ ratio much higher than 2 and is therefore not ideally suited for producing synfuels.

There are several things to note about the above synfuel production techniques. First, in the case of coal gasification, to obtain the required $\mathrm{H}_{2} / \mathrm{CO}$ ratio of 2 , additional $\mathrm{H}_{2}$ is required. This is provided via the water gas shift reaction at the expense of $\mathrm{CO}_{2}$ production. Second, both schemes consume fossil fuels. Finally, both processes result in the production of the greenhouse gas $\mathrm{CO}_{2}$.

A sustainable and more environmentally friendly method of synfuel production entails using captured $\mathrm{CO}_{2}$ 
as the carbon source and water splitting to supply hydrogen $[3,4]$ :

$$
\begin{array}{ll}
\text { Water splitting } & 3 \mathrm{H}_{2} \mathrm{O} \rightarrow 3 \mathrm{H}_{2}+3 / 2 \mathrm{O}_{2} \\
\text { Reverse water gas shift: } & \mathrm{CO}_{2}+\mathrm{H}_{2} \rightarrow \mathrm{CO}+\mathrm{H}_{2} \mathrm{O} \\
\text { F-T reaction } & \mathrm{CO}+2 \mathrm{H}_{2} \rightarrow \mathrm{CH}_{2}+\mathrm{H}_{2} \mathrm{O} \\
\text { Net reaction } & \mathrm{CO}_{2}+\mathrm{H}_{2} \mathrm{O} \rightarrow \mathrm{CH}_{2}+3 / 2 \mathrm{O}_{2} .
\end{array}
$$

In this reaction scheme, the greenhouse gas $\mathrm{CO}_{2}$ is consumed rather than produced and no fossil fuels are consumed.

The reaction pathway proposed above relies upon a suitable renewable energy powered and/or nuclear powered water-splitting technologies for carbon-free sustainable hydrogen production. The Idaho National Laboratory (INL) has been researching the use of solidoxide fuel cell technology to electrolyze steam for largescale nuclear-powered hydrogen production. The scope of activities under the INL High Temperature Steam Electrolysis (HTSE) program includes computational fluid dynamics modeling, process flow sheet analyses, and experimental testing. Scales of experimental testing extend from $\sim 2$ watt button cell tests to $15 \mathrm{~kW}$ multi-stack tests.

Parallel to the INL high temperature electrolysis activities, the INL Energy Security Initiative has been established to help achieve energy security for the United States. The Energy Security Initiative studies hybrid energy systems that are based upon tightly-coupled chemical processes, more efficient reactor designs, improved or new heat transfer modes, new materials, and new measurement / control systems.

Due to the difficulty of small scale Fischer-Tropsch processing, it was decided to postpone Fischer-Tropsch studies and instead produce synthetic methane as Phase I of the INL Energy Security Initiative:

$$
\begin{array}{ll}
\text { Water splitting } & 4 \mathrm{H}_{2} \mathrm{O} \rightarrow 4 \mathrm{H}_{2}+2 \mathrm{O}_{2} \\
\text { Reverse water gas shift: } & \mathrm{CO}_{2}+\mathrm{H}_{2} \rightarrow \mathrm{CO}+\mathrm{H}_{2} \mathrm{O} \\
\text { Methanation reaction } & \mathrm{CO}+3 \mathrm{H}_{2} \rightarrow \mathrm{CH}_{4}+\mathrm{H}_{2} \mathrm{O} \\
\text { Net reaction } & \mathrm{CO}_{2}+2 \mathrm{H}_{2} \mathrm{O} \rightarrow \mathrm{CH}_{4}+2 \mathrm{O}_{2} .
\end{array}
$$

An existing high temperature electrolysis testing apparatus was coupled to a new reverse shift reactor and methanation reactor to produce synthetic natural gas via the above reaction pathway (Eqs. 12-15). As part of a 2500 hour long-duration HTSE test, 60 hours of integrated tests were conducted. All hydrogen was provided via HTSE. $\mathrm{CO}_{2}$ was separated from a simulated flue gas stack (circa $15 \% \mathrm{CO}_{2}$ in humid nitrogen) using a nitrogen purification membrane and directed to the shift reactor where $\mathrm{CO}$ was produced using the hydrogen supplied by HTSE. The resulting syngas mixture continued to a methanation reactor. Measurements of the product gas composition were taken with a four-channel micro-GC.

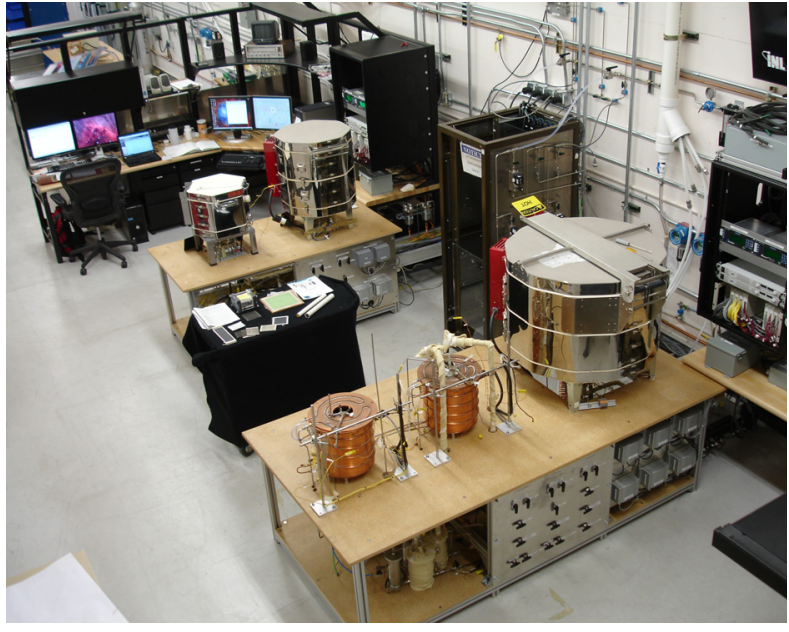

Figure 1. INL high-temperature electrolysis laboratory.

\section{EXPERIMENTAL TESTING FACILITY}

\section{I.A. High-Temperature Steam Electrolysis Facility}

A comprehensive discussion of the INL high temperature solid oxide electrolysis bench scale experiment is presented elsewhere [5]. This same facility is used for button cell testing as well as stack testing. The facility incorporates 5 independent button cell / stack testing stations that can be used for steam electrolysis as well as steam $/ \mathrm{CO}_{2}$ coelectrolysis testing. A photograph of the laboratory is found in Fig. 1 and a simplified schematic of one stack testing station follows in Fig. 2. Primary components include gas supply cylinders, massflow controllers, a humidifier, dewpoint measurement stations, temperature and pressure measurement, high temperature furnace, and a solid oxide electrolysis stack. Nitrogen is used as an inert carrier gas. The use of a carrier gas allows for independent variation of both the partial pressures and the flow rates of the inlet steam, and

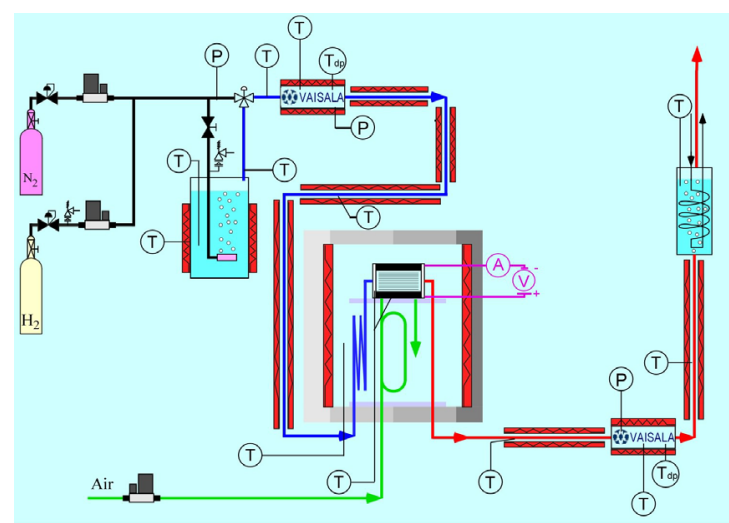

Figure 2. Simplified schematic of INL electrolysis / coelectrolysis stack test apparatus. 
hydrogen gases while continuing to operate near atmospheric pressure. The flow rates of nitrogen, hydrogen, and air are established by means of precision mass-flow controllers. Air flow to the stack is supplied by the shop air system, after passing through a two-stage extractor / dryer unit.

Downstream of the mass-flow controllers, nitrogen is mixed with hydrogen gas. Hydrogen is included in the inlet flow as a reducing gas in order to prevent oxidation of the Nickel cermet electrode material. The nitrogen / hydrogen gas mixture is mixed with steam by means of a heated water bath. The humidifier water temperature is maintained at a constant setpoint value using computerized feedback control. The dewpoint temperature of the nitrogen / hydrogen / steam gas mixture exiting the humidifier is monitored continuously using a precision dewpoint sensor. Pressure is also measured at the dewpoint measurement stations using absolute pressure transducers. Local stream pressure information is required to determine the mole fraction of steam in the gas mixture at the dew point measurement station. Since the nitrogen and hydrogen flow rates are fixed by the mass flow controllers, and the steam partial pressure is fixed by the bath temperature, the complete inlet gas composition is precisely known at all times. All gas lines located downstream of the humidifier are heattraced in order to prevent steam condensation. Gas line temperatures are monitored by thermocouples and controlled by means of computer-controlled SCRs.

The electrolysis product stream exiting the furnace is directed towards a second dewpoint sensor upon exiting the furnace and then to a condenser through a heat-traced line. The condenser removes most of the residual steam from the exhaust. The final exhaust stream is vented outside the laboratory through the roof.

The rate of steam electrolysis is measured via two different, independent methods: 1) electrical current through the stack, and 2) the measured change in inlet and outlet steam concentrations as measured by the on-line dew point sensors.

The inlet gas mixture is directed to the high temperature furnace, which heats and maintains the electrolyzer at the appropriate test temperature via computer-based feedback control. The furnace also preheats the inlet gas mixture and the air sweep gas. A photograph of a $10 \mathrm{~cm}$ x $10 \mathrm{~cm} 10$ cell stack, mounted on its inconel test fixture and resting on the furnace base, is shown in Fig. 3. The stacks were fabricated by Ceramatec, Inc., of Salt Lake City, UT. The stacks have a per-cell active area of $64 \mathrm{~cm}^{2}(10 \mathrm{~cm} \mathrm{x} 10 \mathrm{~cm}$ cells $)$ for a total active area of $640 \mathrm{~cm}^{2}$.

\section{I.B. Electrolysis Stack}

Planar stacks used for testing by the INL are fabricated by Ceramatec, Inc., of Salt Lake City, UT. The

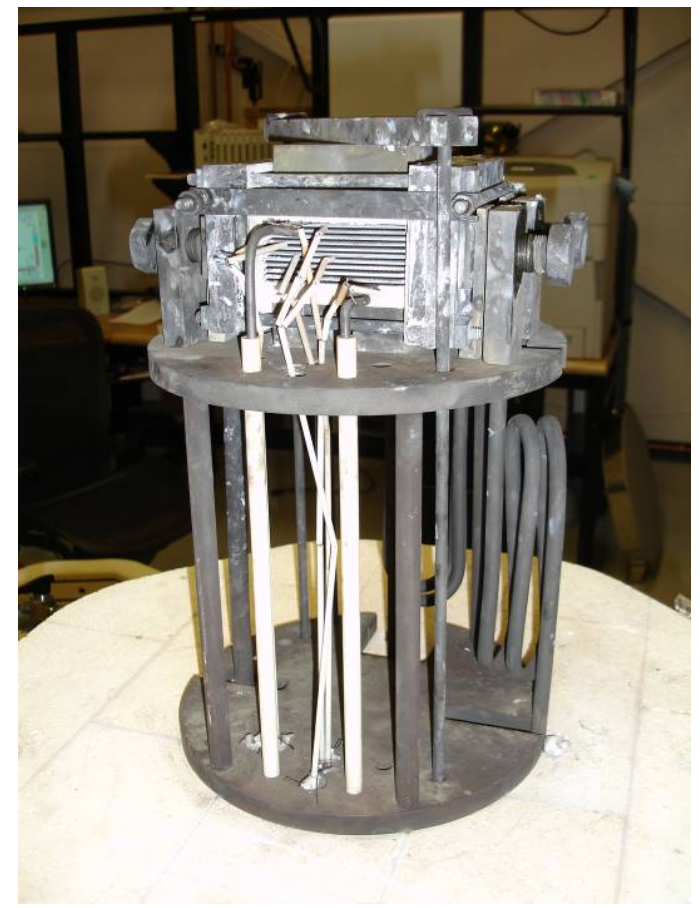

Figure 3. 10-cell $10 \mathrm{~cm} \mathrm{x} 10 \mathrm{~cm}$ stack mounted on test fixture on furnace base, ready to test.

internal components of a typical stack are shown in Fig. 4 and are comprised as follows. The interconnect plate is fabricated primarily from ferritic stainless steel. It includes an impermeable separator plate $(\sim 0.46 \mathrm{~mm}$ thick $)$ with edge rails and two corrugated flow fields, one on the sweep-gas side and one on the steam / hydrogen side. The height of the flow fields is $1.0 \mathrm{~mm}$. Each flow field includes 32 perforated flow channels across its width to provide uniform gas-flow distribution. The steam / hydrogen flow fields are fabricated from nickel foil. The air-sweep flow fields are made from ferritic stainless steel. The interconnect plates and flow fields also serve as electrical conductors and current distributors. To

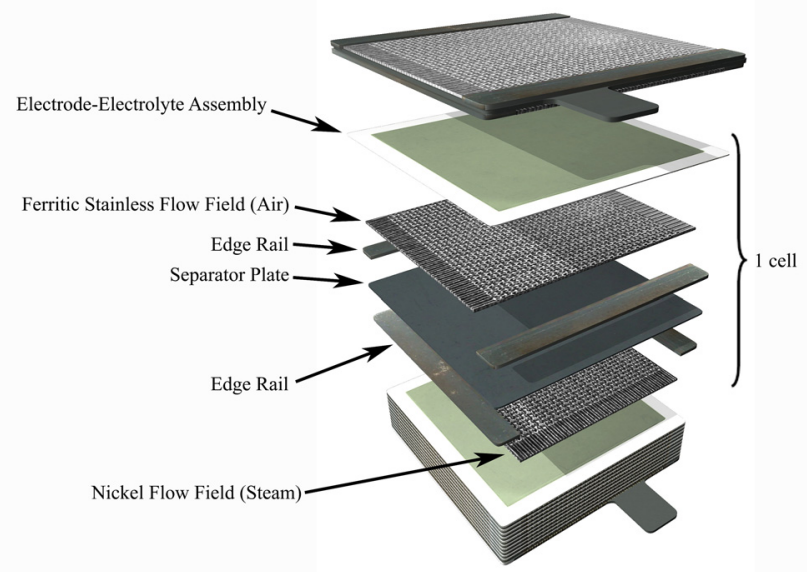

Figure 4. Diagram of solid-oxide stack components. 
improve performance, the sweep-side separator plates and flow fields treated with a spinel coating. On the steam / hydrogen side of the separator plate, a thin $(\sim 10 \mu \mathrm{m})$ nickel metal coating is applied.

The electrolyte is partially-scandia-stabilized zirconia, $\sim 140 \mu \mathrm{m}$ thick. The steam / hydrogen electrode (cathode in the electrolysis mode) is graded, with a nickel cermet layer $(\sim 13 \mu \mathrm{m})$ immediately adjacent to the electrolyte and a pure nickel outer layer $(\sim 40 \mu \mathrm{m})$.

The sweep-side or oxygen-side electrode (anode in the electrolysis mode) and bond layer are composed of cobalt ferrite.

\section{I.C. INL Energy Security Initiative Phase I Facility}

The HYTEST Phase I setup was constructed adjacent to the HTSE test facility described above. The INL Energy Security Initiative Phase I facility (hereafter referred to as Phase I) was designed to couple the HTSE testing operations with reactor components in order to use the hydrogen produced by ongoing HTSE testing. In this manner, the quality and dynamic production of hydrogen could be investigated concurrently with Phase I activities that address: 1) feedstock conversion, 2) energy integration, 3) energy storage and product synthesis, 4) by-product management (i.e. $\mathrm{CO}_{2}$ capture, recycle, and reduction to fuels and chemicals), and 5) system simulation and process monitoring and control.

A photograph of the Phase I setup is included in Fig. 5. This setup integrates four reactors: 1) a $10 \mathrm{~cm} \mathrm{x} 10 \mathrm{~cm}$ x 10 cell HTSE stack (described above), 2) an heated tubular reactor capable of being heated to $1200^{\circ} \mathrm{C}$ to perform steam-methane reforming and reverse-shifting of $\mathrm{CO}_{2}$ with $\mathrm{H}_{2}, 3$ ) a high-pressure fixed-bed catalytic synthetic fuels reactor, and 4) a $\mathrm{CO}_{2}$-separation membrane reactor. The reactors are set up for integrated testing, including recycle of the streams necessary to attain high conversion efficiency and to investigate system dynamics and stability. The entire process setup (not including the HTSE stack) is contained in a transportable enclosure that provides access to components through Lexan-Glass ${ }^{\mathrm{TM}}$ windows on each side of the module. Electrical power is supplied through a single power cord (208/120 volt, $100 \mathrm{amp}$ ), which can be disconnected and locked-out for electrical installations and maintenance. The module is ventilated with a variable-speed blower mounted on the building roof. Airflow checks indicated that face velocities greater 100 $\mathrm{ft} / \mathrm{s}$ can be achieved, even when two windows are open at medium fan speeds (about 1,500 scfm volumetric flow). An air damper is installed on the module to allow for up to 2,500 scfm of airflow. The multiple windows and damper provide excellent air draft throughout the enclosure with the ability to achieve 3 to 6 air turnovers per minute.

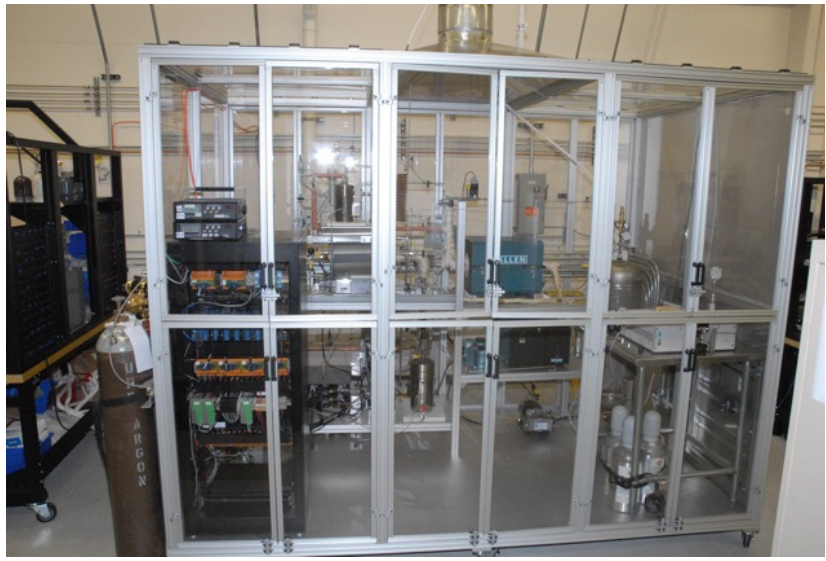

Figure 5. Photograph of INL Energy Security Initiative Phase I experimental facility.

The Phase I process diagram is found in Fig. 6. The process system is mainly constructed of stainless steel vessels and tubing with typical Swagelok fittings. Flow is established by applying positive pressures of less than 30 psig to electronic gas mass flow controllers, which regulate the total flow through the methanation reactor at approximately $0.25-5.0 \mathrm{slpm}$.

Compressed gas mixtures supply reactant $\mathrm{CO}, \mathrm{CO}_{2}$, $\mathrm{CH}_{4}$ and diluent/purge $\mathrm{N}_{2}$. After system checkout, all of the test hydrogen was supplied by the coupled HTSE reactor. A hydrogen pump is used to compress the HTSE-produced hydrogen to $45 \mathrm{psig}$. The pump is controlled electronically to maintain the hydrogen tank pressure between 35 psig and 45 psig. Hydrogen makeup gas from compressed gas cylinders can be provided, but was not necessary for the current tests. Spreadsheet calculations were used to determine the flow rates of individual reactants to attain the desired operating conditions and reactant concentrations.

Reactant and recycle gas compositions are achieved by metering gases in the proper ratios with calibrated mass-flow controllers and verified by on-line sample collection and monitoring at the points marked in the process diagram (Fig. 6). Stream flow rates, compositions, pressure, and temperature conditions are continuously monitored and controlled to ensure safe conditions and proper flow balances. Automatic shutoff solenoid-actuated valves are installed in the system in the event that reactor temperatures fall below safe limits. This feature is incorporated to prevent the formation of nickel carbonyls or hazardous gas leaks into the general occupancy area of the lab.

Steam is introduced into the system using a water evaporation flash pot. A metering pump injects a controlled amount of water semi-continuously into the heated steam generator vessel through a $1 / 4$ " stainless steel tube. The water vaporized in the steam generator discharges into the main gas line downstream of the gas pre-heater. A 2" dip tube directs the water feed flow 


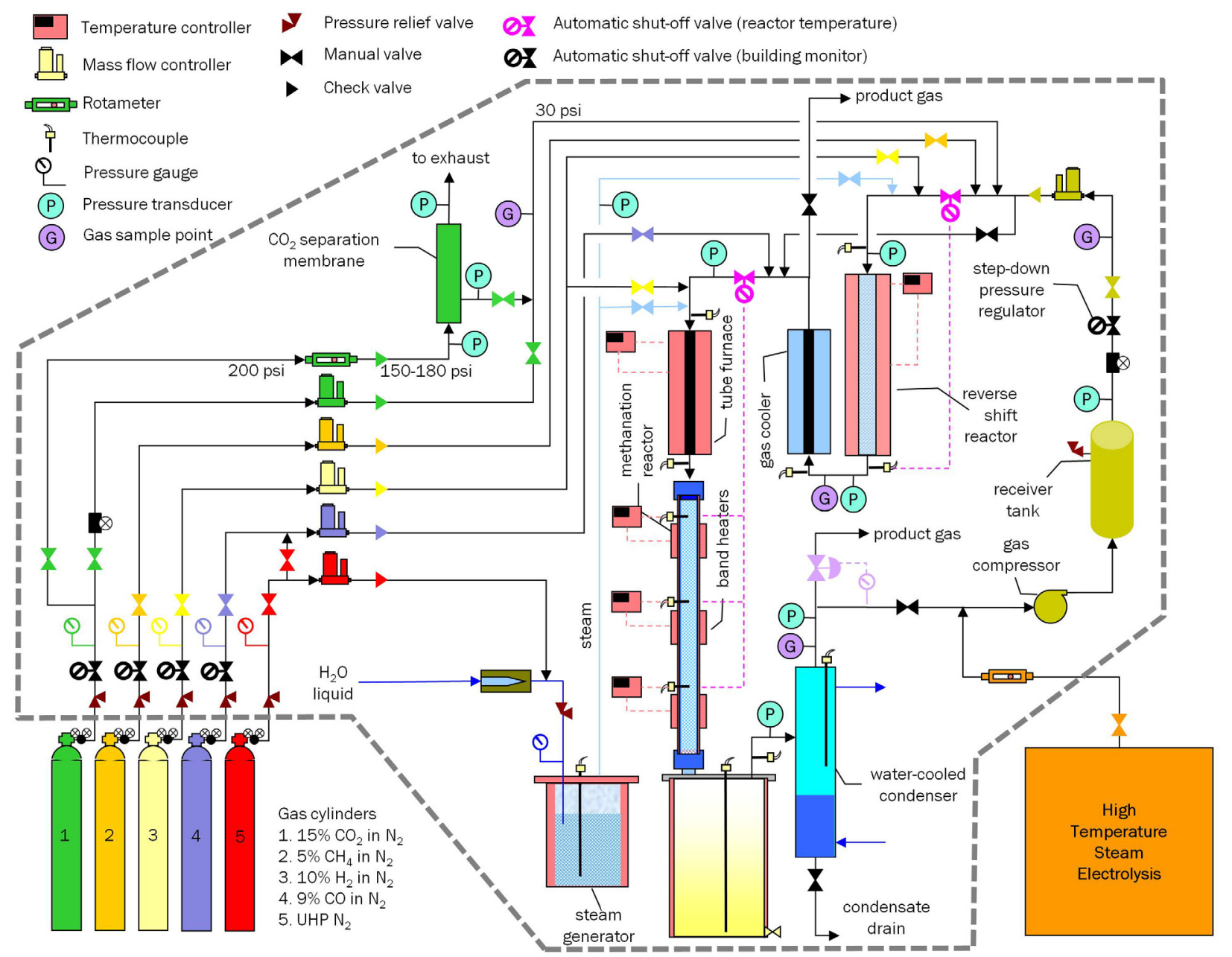

Figure 6. INL Energy Security Initiative Phase I process equipment schematic.

towards the bottom of the vessel. A stainless steel mesh is placed in the vessel to disengage moisture droplets ejected from the boiling film of water. A thermocouple measures the interior temperature of the steam generator.

Carbon dioxide was separated from a simulated flue gas stack (approximately $15 \% \mathrm{CO}_{2}$ in nitrogen) using a

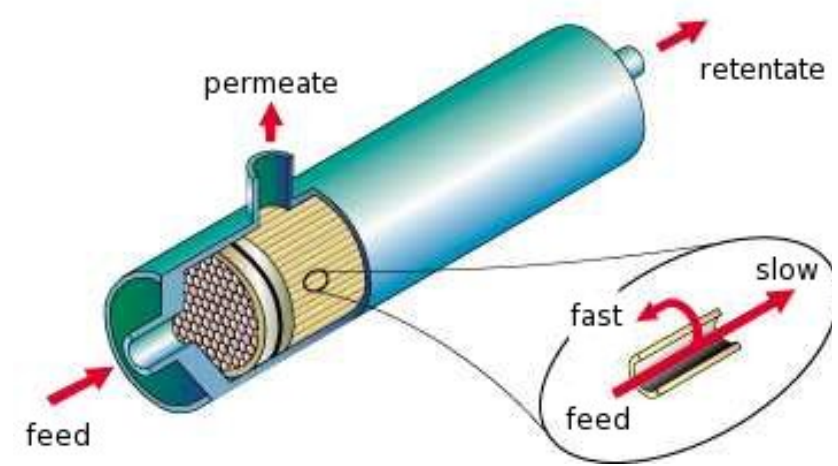

Figure 7. Schematic of the tube-feed, hollow-fiber membrane module. nitrogen purification membrane (Fig. 7). The separated $\mathrm{CO}_{2}$ was diverted to the shift reactor, where it was reverse-shifted to carbon monoxide (CO) using hydrogen supplied by HTSE. The resulting $\mathrm{CO}-\mathrm{H}_{2}$ syngas mixture was fed to the methanation reactor.

The methanation reactor is a High Pressure Equipment Company MS-19 Micro Series Reactor with an effective height of 20 inches and a $9 / 16$ " internal diameter. This tubular micro-reactor is fabricated from 316 SST with a design pressure rating of 1200 psi at $450^{\circ} \mathrm{C}$. The reactor was charged with approximately $70 \mathrm{~g}$ of pelletized catalyst, supported over a stainless steel support screen. Process temperatures are continuously monitored by three evenly-spaced thermocouples near the top, middle, and end of the catalyst bed. Feedbackcontrolled band heaters are used to maintain the reactor temperatures. Six 1-1/2" wide, 1" ID Watlow ${ }^{\mathrm{TM}}$ mineralinsulted band heaters are evenly spaced along the length of the reactor barrel. For the current tests, the reactor inlet and interior temperatures were maintained above $250^{\circ} \mathrm{C}$ to prevent possible formation of nickel 
tetracarbonyl, $\mathrm{Ni}(\mathrm{CO})_{4}$, which can form at temperatures below approximately $150^{\circ} \mathrm{C}$.

Gas compositions were measured using an Agilent 3000 Micro Gas Chromatograph, configured with four channels. The GC is outfitted with two identical mole sieve columns, one Plot Q column, and one Plot U column. Each of the gas species was detected on two or more columns of the GC, providing a useful cross-check of the data. Argon carrier gas was used for all four of the channels in this test. Various GC methods and programs were developed and tested using calibration gases. This made it possible to cover the wide range of concentrations from ppm to over $90 \mathrm{vol. \%}$. Injection times were also varied to enable greater flexibility of range. Instrument calibration was performed weekly, but retention times and response factors remained relatively constant throughout the testing.

Data logging was accomplished with the control program and gas chromatograph. In addition, manual data collection sheets were developed to keep periodic records of temperatures, pressures, flow rates, and gas species measurements.

\section{EXPERIMENTAL RESULTS}

Results will be discussed roughly in order by which reactants flow through the integrated system: first, hightemperature steam electrolysis; second, $\mathrm{CO}_{2}$ separation membrane; third, reverse-shift reactor; and finally, methanation reactor.

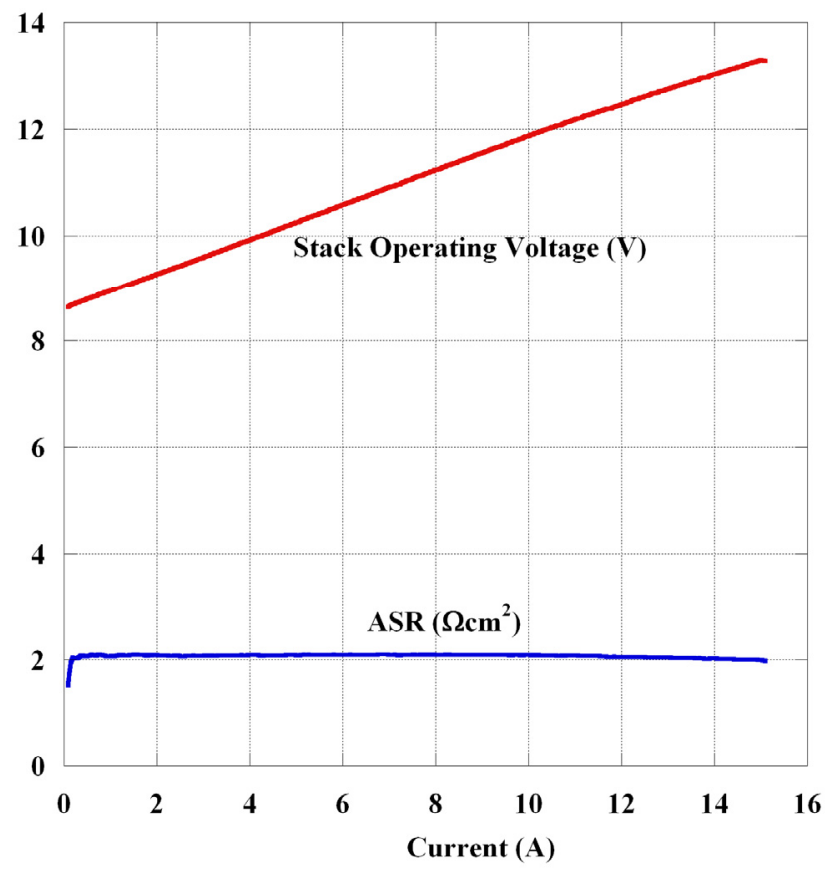

Figure 8. Initial polarization curve for stack.
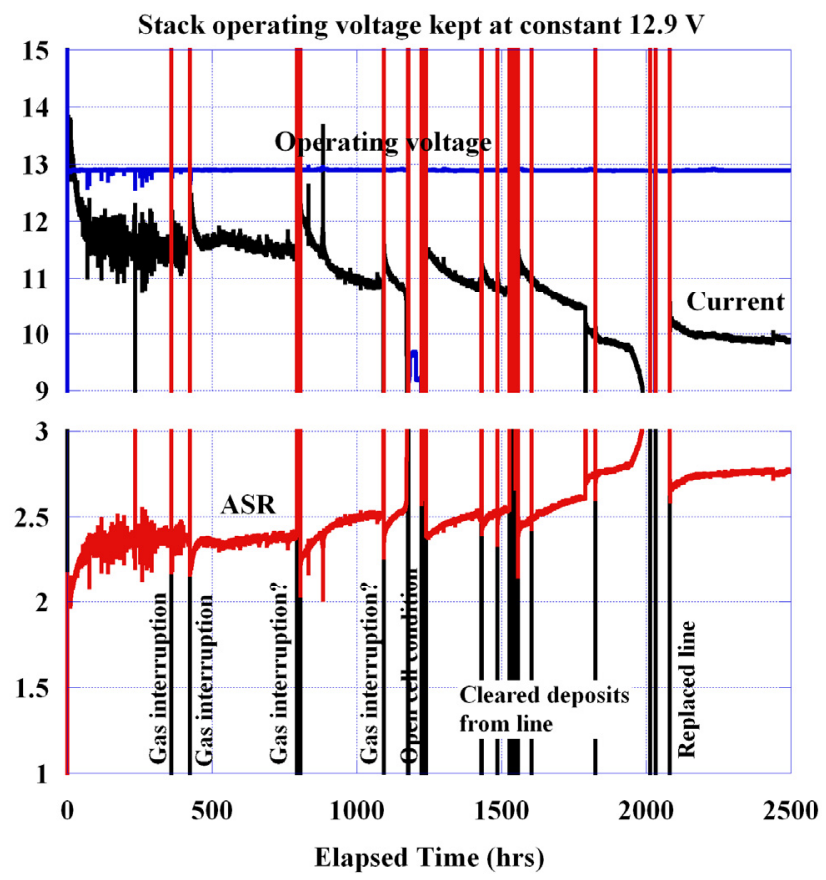

Figure 9. ASR, current, and voltage for the 2500 hour 10 -cell stack test.

\section{II.A. Electrolysis Stack}

Testing commenced with an inlet hydrogen flow rate of $800 \mathrm{sccm}$, nitrogen flow rate of $1600 \mathrm{sccm}$, and furnace temperature of $800^{\circ} \mathrm{C}$. The inlet dew point temperature was $82^{\circ} \mathrm{C}$. This corresponds to an inlet steam mole fraction of 0.6. The theoretical open cell potential for these inlet conditions was calculated to be $0.87 \mathrm{~V}$. The measured open cell potential was $0.86 \mathrm{~V}$.

Fig. 8 presents the results of an initial polarization curve / voltage sweep performed under the above conditions. The voltage was automatically swept from open cell to the thermal neutral voltage of 1.29 volts / cell for the operating temperature of $800^{\circ} \mathrm{C}$. The peak current was measured to be $15.1 \mathrm{~A}$, corresponding to a peak current density of $0.24 \mathrm{~A} / \mathrm{cm}^{2}$. Measured per-cell area specific resistance (ASR) values were around $2 \Omega \mathrm{cm}^{2}$.

Long-duration steady-state operations at the thermal neutral voltage of $12.9 \mathrm{~V}$ began on May 29 and completed 2500 hours at constant input on September 10. A summary graph of the results of the test is shown in Fig. 9. This graph shows the operating voltage, stack current and ASR with data recorded every five minutes. The stack operating conditions were kept constant at the same values as those for the polarization curve test discussed above.

Several events disrupted the steady-state testing. It is not clear whether these events affected the long-term performance of the stack. Most of these disruptions involved interruptions of inlet gas flows $\left(\mathrm{N}_{2}\right.$ and $\left.\mathrm{H}_{2}\right)$, 
caused by problems with the gas mass flow controller electronics. Later in testing (beyond 1200 hours), the gas lines in the gas humidifier would become periodically clogged, also interrupting gas flows to the stack. Apparently the laboratory water demineralization system was not operating correctly. As a result, several analog pressure gauges were installed to monitor the humidifier back pressure such that lines could be replaced before gas flow was interrupted. If blockage of gas flow occurred, the stack would not receive sufficient steam and electrical current would drop drastically due to steam starvation.

During the first 60 hours, the nickel oxide in the hydrogen electrode is being reduced and all of the components of the cell are sintering. The ASR of the stack reached $2.3 \Omega-\mathrm{cm}^{2}$ at 60 hours elapsed test time, at which point it stabilized. Beyond 60 hours elapsed test time, the average rate of degradation was $8.15 \%$ per 1000 hours.

At the conclusion of 2500 hours the stack had a percell ASR of $2.75 \Omega \mathrm{cm}^{2}$. The flow rate of HTSE products was approximately $1400 \mathrm{~cm}^{3} / \mathrm{min}$. The hydrogen production rate as measured by the stack current (Faraday's Law) was $690 \mathrm{sccm}$ (41.4 N-liters/hour, 3.7 $\mathrm{g} / \mathrm{h})$. This corresponds to an outlet composition of approximately $49 \% \quad \mathrm{H}_{2}$ and $51 \% \quad \mathrm{~N}_{2}$ by volume. Subsequent gas chromatograph analysis indicated the product mixture was closer to $45 \% \mathrm{H}_{2}$ and $55 \% \mathrm{~N}_{2}$ by volume. The stack electrical current was $9.89 \mathrm{~A}$.

\section{II.B. $\mathrm{CO}_{2}$ Separation and Methanation}

The product stream from the high temperature steam electrolysis stack was captured, pressurized, and stored in a surge tank. A feedback-controlled hydrogen pump pressurized the surge tank to 35 to $45 \mathrm{psig}$. The $\mathrm{CO}_{2}$ membrane separation system was run for approximately 8 hours of integrated operations with the HTSE experiment and the high-temperature gas-shift reactor. A model flue gas $\left(15 \% \mathrm{CO}_{2}\right.$ in $\left.\mathrm{N}_{2}\right)$ was fed to the membrane system. The retentate (mostly $\mathrm{N}_{2}$ ) was discharged to the exhaust, and the permeate (concentrated $\mathrm{CO}_{2}$ in $\mathrm{N}_{2}$ ) was mixed with $\mathrm{H}_{2} / \mathrm{N}_{2}$ from the HTSE experiment and forwarded to the gas-shift reactor. Test conditions and results from the membrane experiment are displayed in Table 1.

Fig. 10 compares the experimental concentration data with predictions from a membrane model. A description of the membrane computational model can be found in [6]. The mole fraction of $\mathrm{CO}_{2}$ in the permeate stream is plotted against the feed flow rate parameter $\mathrm{n}_{\text {feed }} / \mathrm{P}_{\text {feed }}$. In these coordinates, the model predictions exhibit nearly linear dependence on the feed flow parameter. This agrees somewhat with the data at low flow rates, but the measurements at high flow rates are sporadic and do not agree well with the model. The disparity is likely due to problems with the experimental setup. The rotametertype flowmeter that was installed upstream of the
Table 1. Membrane test conditions / outlet $\mathrm{CO}_{2}$ concentration.

\begin{tabular}{|c|ccccc|}
\hline \multicolumn{2}{|c|}{$\begin{array}{c}\mathrm{n}_{\text {feed }} \\
{[\mathrm{mol} / \mathrm{s}]}\end{array}$} & $\begin{array}{c}\mathrm{P}_{\text {feed }} \\
{[\mathrm{psig}]}\end{array}$ & $\begin{array}{c}\mathrm{P}_{\text {retentate }} \\
{[\mathrm{psig}]}\end{array}$ & $\begin{array}{c}\mathrm{P}_{\text {permeate }} \\
{[\mathrm{psig}]}\end{array}$ & $\begin{array}{c}\text { Permeate } \\
\mathrm{CO}_{2} \text { mol\% }\end{array}$ \\
\hline 1 & 1.48 & 120 & 117 & 7.34 & 16.0 \\
2 & 1.68 & 120 & 116 & 7.92 & 24.7 \\
3 & 2.22 & 120 & 120 & 8.12 & 19.9 \\
4 & 1.3 & 140 & 132 & 16.8 & 19.8 \\
5 & 2.59 & 140 & 133 & 21.9 & 25.6 \\
6 & 2.59 & 140 & 133 & 9.64 & 21.9 \\
7 & 1.63 & 160 & 152 & 11.7 & 20.5 \\
8 & 2.76 & 160 & 150 & 12.8 & 24.2 \\
\hline
\end{tabular}

membrane unit was inadequate to provide consistent quantification of the flow of feed gas to the membrane. These unreliable measurements were difficult to reconcile with the composition data from the gas chromatograph.

Attempts to perform reverse $\mathrm{CO}_{2}$ shift with hydrogen in a tubular reactor were partially successful. The tubular reactor was charged with a steam methane reforming catalyst. Unfortunately, a small, but significant amount of $\mathrm{CO}_{2}$ was converted to condensed carbon (or coke) on the surfaces of the heated tube. This carbon buildup contributed to problematic catalyst coking. Nonetheless, Fig. 11 and 12 compare measured data with equilibrium conditions for the test to determine the extent that $\mathrm{CO}_{2}$ was converted to $\mathrm{CO}$ with $\mathrm{H}_{2}$ following the water-gas shift reaction. Excess hydrogen supplied from the HTSE was combined with $\mathrm{CO}_{2}$ in a dry inlet stream. This gave a maximum driving force to convert $\mathrm{CO}_{2}$ to $\mathrm{CO}$. Data were collected as the furnace temperature was increased and then decreased. The flowrate was increased during the temperature descent to investigate the affect of residence time and pressure.

The methanation synfuels reactor was operated in concert with the HTSE experiment for more than 30 hours

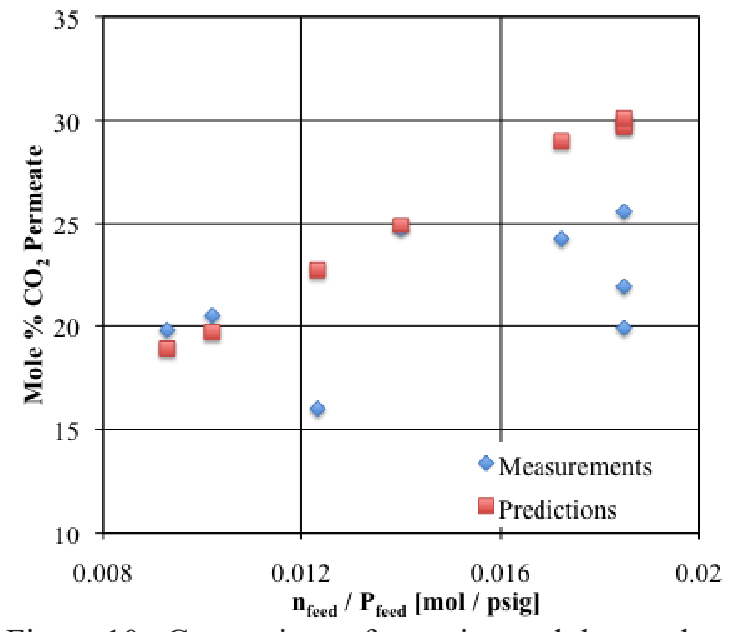

Figure 10. Comparison of experimental data and model predictions for membrane $\mathrm{CO}_{2} / \mathrm{N}_{2}$ separation. 


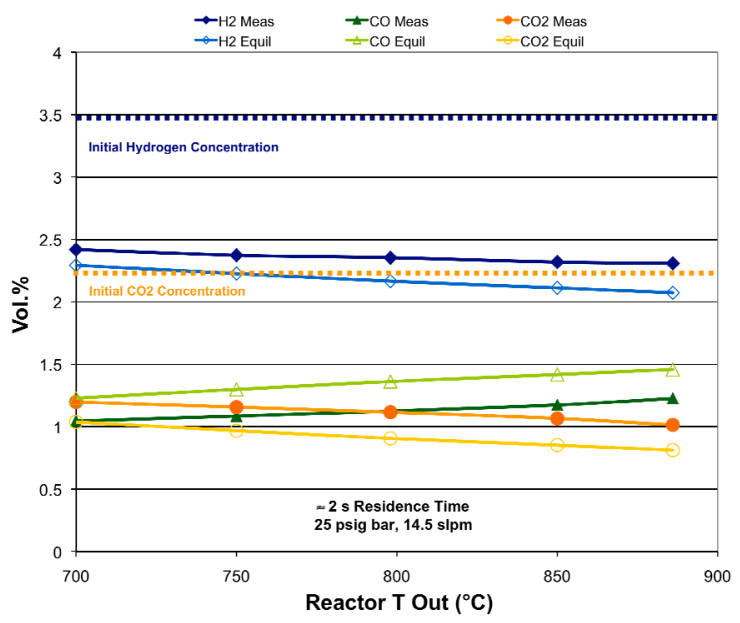

Figure 11. Comparison of measured data with watergas shift equilibrium conditions, $2 \mathrm{sec}$ residence.

of integrated testing. During methanation testing, a total inlet flow rate of approximately 2 slpm was maintained. Table 2 lists the operating conditions for the methanation parametric studies conducted.

In general, the fractional conversion of $\mathrm{CO}$ to $\mathrm{CH}_{4}$ was greater at higher pressures and lower temperatures. This is consistent with Le Chatelier's principle for the exothermic methanation reaction where the total number of moles decreases with the extent of reaction. The extent of methanation tended to over $70 \%$ conversion regardless of reactor temperature (ranging from 275 to $325 \mathrm{C}$ ) or reactor pressure (ranging from 5 to $25 \mathrm{psig}$ ). The time to reach steady state, however, did depend on the initial conditions.

\section{CONCLUSIONS}

The HYTEST Phase I facility at the INL operated in conjunction with the HTSE experiment for over 60 hours of integrated testing. During operations, the synfuels

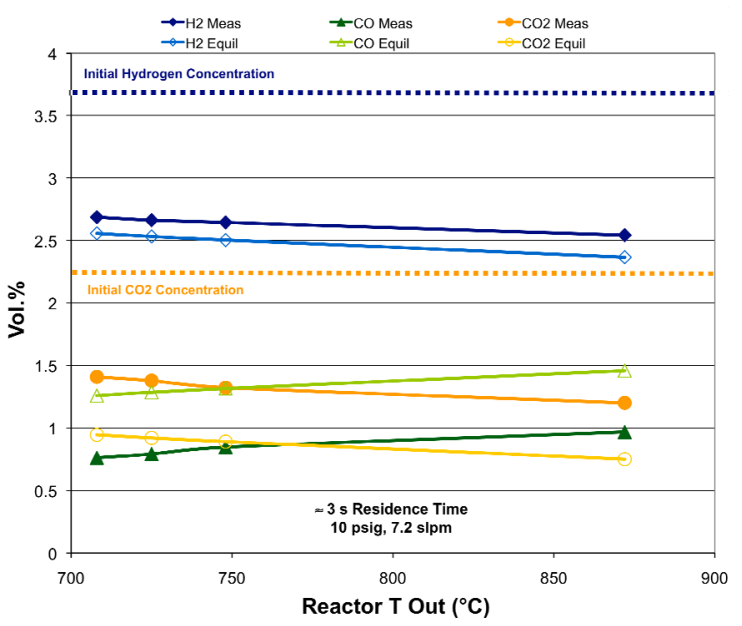

Figure 12. Comparison of measured data with watergas shift equilibrium conditions, $3 \mathrm{sec}$ residence.

reactor, $\mathrm{CO}_{2}$ membrane separator, and high-temperature shift reactor were operated in several configurations to demonstrate various aspects related to hybrid energy systems and synfuels production. This facility represents a major accomplishment within the Energy Security Initiative as it provides a flexible and reconfigurable testbed for laboratory-scale demonstrations of hybrid-energy concepts and technologies.

\section{ACKNOWLEDGMENTS}

This work was supported by the U.S. Department of Energy, Office of Nuclear Energy, Next Generation Nuclear Plant program as well as the Idaho National Laboratory, Laboratory Directed Research and Development Program. The Idaho National Laboratory is operated for the U.S. Department of Energy's Office of Nuclear Energy by the Battelle Energy Alliance under contract number DE-AC07-05ID14517.

Table 2. Methanation results

\begin{tabular}{|c|c|c|c|c|c|c|c|c|}
\hline Test & $\begin{array}{c}\mathrm{T}_{\text {reactor }} \\
{[\mathrm{C}]}\end{array}$ & $\begin{array}{c}\mathrm{P}_{\text {inlet }} \\
\text { [psig] }\end{array}$ & $\begin{array}{l}9 \% \mathrm{CO} \\
\text { SLPM }\end{array}$ & $\begin{array}{c}45 \% \mathrm{H}_{2} \\
\text { SLPM }\end{array}$ & $\begin{array}{c}100 \% \mathrm{~N}_{2} \\
\text { SLPM }\end{array}$ & $\begin{array}{c}\mathrm{H}_{2} \mathrm{O} \\
\text { SLPM }\end{array}$ & $\begin{array}{l}\text { Outlet } \mathrm{CH}_{4} \\
\text { mole fraction } \\
\text { dry basis }\end{array}$ & $\begin{array}{c}\text { Fractional } \\
\text { Conversion }\end{array}$ \\
\hline 1 & 325.1 & 23.70 & 0.65 & 0.48 & 0.88 & 0 & 0.0223 & 0.70 \\
\hline 2 & 325.1 & 6.50 & 0.65 & 0.48 & 0.88 & 0 & 0.0211 & 0.67 \\
\hline 3 & 297.6 & 6.22 & 0.65 & 0.48 & 0.88 & 0 & 0.0228 & 0.72 \\
\hline 4 & 272.6 & 5.95 & 0.65 & 0.48 & 0.88 & 0 & 0.0235 & 0.74 \\
\hline 5 & 272.6 & 24.20 & 0.65 & 0.48 & 0.88 & 0 & 0.0255 & 0.80 \\
\hline 6 & 297.6 & 23.60 & 0.65 & 0.48 & 0.88 & 0 & 0.0248 & 0.78 \\
\hline 7 & 321.5 & 26.20 & 0.65 & 0.48 & 0.88 & 1.06 & 0.0016 & 0.07 \\
\hline 8 & 297.6 & 5.61 & 0.97 & 0.72 & 1.28 & 0 & 0.0245 & 0.77 \\
\hline 9 & 297.7 & 6.39 & 1.30 & 0.96 & 1.76 & 0 & 0.0244 & 0.78 \\
\hline
\end{tabular}




\section{REFERENCES}

1. U.S. Energy Information Administration Short-Term Energy Outlook, www.eia.doe.gov/steo, Jan 12, 2010.

2. The Oil Drum Peak Oil Update, www.theoildrum.com/tag/update, July 2009.

3. Schultz, K., et. al., "Hydrogen and Synthetic Hydrocarbon Fuels - A Natural Synergy," National Hydrogen Association Annual Meeting, 13-16 March 2006, Long Beach, Ca.

4. Schultz, K., et. al., "Synthesis of Hydrocarbon Fuels Using Renewable and Nuclear Energy," Nuclear Technology, Vol. 166, April 2009.

5. Stoots, C., O'Brien, J., Herring, J., and Hartvigsen, J., "Syngas Production via High-Temperature Coelectrolysis of Steam and Carbon Dioxide," Journal of Fuel Cell Science and Technology, Vol 6, February, 2009.

6. Shunn, L., Boardman, R., Cherry, S., and Rieger, C., "HYTEST Phase I Facility Commissioning and Modeling," INL External Technical Report INLEXT-09-16961, Sept 2009. 